\title{
A TUDOMÁNYOS KOMMUNIKÁCIÓ TÖRTÉNETE A JOURNAL DES SÇAVANS-TÓL AZ OPEN ACCESS-IG
}

\author{
BILICSI ERIKA \\ MTA Könyvtár és Információs Központ Szakinformatikai Osztály, osztályvezető
}

\begin{abstract}
ABSZTRAKT
Bár a tudományos kommunikáció kezdetei az ókorra vezethetők vissza, a tudományos publikálás mai gyakorlata, vagyis a tudományos folyóirat-kiadás a 17. században alakult ki. Két évszázaddal később már a lektorált folyóiratokban való publikálás határozta meg a kutatók és a kutatóintézetek hatékonyságát és elismertségét. A 20. század második felében jelentkezett az ún. „folyóiratkrízis": a hagyományos publikálási gyakorlat nem volt képes a hatalmas információtömeg gyors közlésére. A helyzet megoldását egy új publikációs modell, az open access közlési forma jelentette, mely a 2000-es évek elején vált mozgalommá. Ebben az új modellben a könyvtárak szerepe is megváltozik. A tudományos közösségnek repozitóriumokra van szüksége, az előfizetési dijakat közlési díjak finanszírozására kell átcsoportosítani, a legnagyobb feladat pedig a kutatók tájékoztatása és a folyamatos segítségnyújtás.
\end{abstract}

A tudományos gondolkodás egyidős az emberiséggel, hiszen az emberben mindig is megvolt az igény, hogy megértse környezetét. Az ismereteket kezdetben kis csoportokban osztották meg, így alakultak ki az első tudományos közösségek, mint például Platón Akadémiája, Arisztotelész Lükeionja, az athéni egyetem, az alexandriai Museion vagy a római iskolák. Megfigyelhető, hogy már ezekben a közösségekben is jelen volt a kutatás mellett az oktatás, mert fontosnak tartották, hogy az ismereteket megosszák a laikusokkal. Ebben az időszakban a tudományos ismereteket nyilvános fórumokon, vitákon, illetve kis példányszámban, kézzel elóállított kéziratok formájában osztották meg.

A tudományos kutatásra nagy hatással volt a 13. században a mai egyetemek elődjeinek kialakulása. Lényegében új rend alakult ki Európában, így például a papság és a mesterek céhei mellett még egy szervezett közösség múködött, melynek tanárok és diákok voltak a résztvevői. Ebben az időben a szellemi közösséget az igazságról való gondolkodás, Isten és az általa teremtett világ megismerése nyújtotta.

A 15. században kezdtek megalakulni az akadémiák, mivel a reneszánsz humanistái az egyetemeken folyó gondolkodásmódot elavultnak tartották. Az egyetemek egyenesen tiltották az új ismeretek oktatását, ragaszkodtak idejétmúlt szabályaikhoz, ezzel gúzsba kötve az intézmény kiváló gondolkodóit. Mivel az oktatók kénytelenek voltak az egyetemek szabályaihoz alkalmazkodni, az akadémiák tagjai a rendszert kritizáló kutatók lettek, mint például Descartes, Pascal, Hobbes, Bacon, Kepler - vagy említhetnénk Newtont, aki elhagyta a cambridge-i egyetemet. Az első ilyen intézmény a francia Académie française volt, melynek 1635-ös alapító okirata a nemzeti nyelv és irodalom ápolását 


\section{BILICSI ERIKA}

tűzte célul. ${ }^{1}$ A 17. században a természettudományok fejlődése számos akadémiát hívott életre, például az angol Royal Society-t vagy a francia Académie de science-t. Ezekben elsősorban az egyes nemzetek tudósai alkottak szellemi közösségeket, de hamar kialakult köztük az együttmúködés, így létrejött a tudományos kutatás nemzetközi hálózata. ${ }^{2}$

A modern tudományos kutatás alapjait a 17. századi akadémiákon szervezték meg. Ezek a szervezetek a megfelelő szellemi közösség mellett a szükséges anyagi hátteret is biztosítani tudták a tudósok számára. A kutatáshoz szükséges eszközök rendelkezésre bocsátásán túl finanszírozni tudták a közlemények megjelentetését. Erre az időszakra tehető az első tudományos folyóiratok megalapítása. Az első európai tudományos folyóirat, a Journal des sçavans 1665. január 5-én jelent meg Denis de Sallo kiadásában, Párizsban, 12 oldalon. Nem sokkal ezután, 1665. március 6-án már a Royal Society kiadásában is megjelent a Philosophical Transactions.

Ne feledjük, hogy a folyóirat-kiadás feltételeit a könyvnyomtatás feltalálása teremtette meg. Az egyetemeken és a korán alakult akadémiákon a tudományos ismeretek megosztása előadások, viták formájában és - más technikai lehetőség nem lévén - kis példányszámú kéziratok terjesztésével valósult meg. Ilyen eszközökkel a tudományos ismeretek terjedése rendkívül lassú volt, és viszonylag kis létszámú közösségekre szorítkozott. A könyvnyomtatás teremtette meg a tudományos folyóirat-kiadás kereteit, mivel lehetővé tette a korábbihoz képest nagy példányszámban, gyorsan és olcsón a tudományos munkák előállítását és terjesztését. A folyóiratok nagy hatással voltak a tudományos közösségek kialakulására, mivel állandóan, periodikusan eljuttatták a tudományos munkákat a kutatók számára. Emellett ebben az időben vált fontossá a szerzőség feltüntetése, elkezdték vizsgálni a közlemények tartalmának helyességét, kialakult a lektorálás rendszere, és az is hatalmas eredménye a folyóirat-kiadásnak, hogy a megjelenô publikációk számára egyfajta megőrzést, visszakereshetőséget biztosított. Ebben az időben a tudományos folyóiratokat tudósok szerkesztették és jelentették meg, de hamar létrejöttek a kiadók, amelyek átvállalták a kiadással járó fáradságos és anyagi kockázatokkal járó feladatokat (finanszírozás, előkészítő munkák, terjesztés stb.).

A 19. században, amikor kezdtek elkülönülni az egyes szakterületek, az egyetemek és az akadémiák mellett kialakult a tudományos közösségek harmadik csoportja, a kutatóintézetek, melyeket a tudományos kutatás változása hívott életre. Valamennyi szervezet közül a kutatóintézet a legszervezettebb, leginkább a tudományos eredmények létrehozását célzó, egy eddiginél jóval szűkebb szakterületre specializált közösség, melyben az oktatásnak nincs helye. Természetesen az előfordult, hogy a kutatóintézetekben dolgozók egyetemen oktattak.

Az elmúlt mintegy 350 év alatt a kutatói közösség megtapasztalta, hogy a kiadók közremúködése nem csak a kiadással felmerülő terheket veszi le a tudósok válláról. A folyóirat-kiadásból üzlet lett, az egyes füzetek megjelentetése igen lassú folyamattá vált, és a kiadók által nyújtott szolgáltatások egyre drágábbak lettek. A folyóiratokban való publikálás kezdett a tudományos eredmények megosztásának egyfajta gátjává válni. 
Az internet és a modern elektronikus eszközök használata forradalmasította a folyóirat-kiadást, hatalmas változást hozva a tudományos kommunikációban. A közlemények száma ugrásszerūen megnôtt, a folyóiratok gombaként kezdtek szaporodni. Bár az elektronikus publikálás jelentősen csökkentette a felmerülő költségeket, a folyóiratok előfizetési díjai mégis soha nem látott összegeket értek el. A tudományos folyóiratkiadás hatalmas profitot termelő üzletté vált, pedig a megjelenő kutatási eredmények közpénzből jönnek létre. A 20. század végén már „folyóiratkrízisről” beszélhetünk, hiszen megfigyelhető, hogy a hagyományos publikációs modell nem képes a hatalmas információtömeg gyors közlésére, az egyre emelkedő előfizetési összegek pedig akadályozzák az ismeretek terjedését. Ekkor terjedt el a gondolat, hogy ha a kutatásokat az adófizetők pénzéből finanszírozzák, akkor annak eredményeit hozzáférhetővé kell tenni a nagyközönség számára is.

A jelenség károsultja a kutató, hiszen a tudományos folyóiratokban megjelent cikkek egyediek, nem helyettesíti egyik a másikat, így elengedhetetlen, hogy a tudósok valamennyi közleményhez hozzáférjenek. A tudományos közlemények hatásának mérésére az egyik legjobb mutató a kapott idézetek száma. De ha a magas előfizetési díj miatt az adott lap kevesek számára érhető el, bármilyen jelentős is a közölt kutatási eredmény, idézettsége nem lesz annyira magas, mint egy olcsóbban előfizethető, ezáltal több olvasó számára hozzáférhető lapban megjelent cikké.

A kialakult helyzetre elsőként a természettudomány reagált: ${ }^{3}$ 1991-ben létrejött az arXiv repozitórium, mely a matematikai, fizikai témájú közlemények kéziratait (preprint) kezdte el gyújteni - hiszen a kiadó a kézirat létrejöttébe nem fektetett pénzt és munkát, hogyan is akadályozhatná annak terjesztését. Ezen a platformon a tudományos eredmények gyors terjedése és felhasználása volt megfigyelhető (a szerzők maguk archiválják közleményeiket, a hozzáférés nyilt), hiszen nem telik el a közlemény beküldése és megjelenése között hosszú idő (kiadóknál akár 1-1,5 év is). 1999-ben az orvos- és élettudományi szakterület is létrehozta a maga repozitóriumát, a PubMed Centralt.

Az open access közlési forma a 2000-es évek elején vált mozgalommá, melynek célja, hogy biztosított legyen a tudományos közleményekhez való szabad hozzáférés mindenki számára. Ezáltal a tudományos kutatások átláthatóvá válnak, eredményeik gyorsabban terjednek, többször felhasználhatóvá válnak, ami nagyobb hatást, jobb hasznosulást, a támogatások eredményesebb felhasználását jelenti. Olyan publikációs metódusról beszélünk, melyben nem a tartalomért, hanem a közlésért kell díjat fizetni. A mai gyakorlatban a szerzô számára - néhány speciális esettől eltekintve, pl. paid open access - a publikálás ingyenes. A kiadók az előfizetésekből finanszírozzák folyóirataik megjelentetését. Emiatt azonban számos esetben kettős, azaz dupla finanszírozás figyelhető meg, ugyanis az adott kutatóhely két ponton is fizet ugyanazért az információért: a kutatást is finanszírozza és a dokumentumot is megvásárolja, amiben a közlemény megjelent.

A helyzet megoldására két open access közlési forma alakult ki: az ún. gold, mely a kiadónál való open access publikálást jelenti, és az ún. green, mely a repozitóriumba történő archiválással valósítja meg a nyílt hozzáférést. 


\section{BILICSI ERIKA}

A tudományos eredmények nyílt hozzáférésével kapcsolatos elvárásokat 2002-ben fogalmazták meg a Budapest Open Access Initiative (BOAI) névre hallgató kezdeményezésben, ${ }^{4}$ egy évvel később pedig a Berlini Deklarációban. ${ }^{5}$ Ezek hatására Magyarországon elsőként az Orsqágos Kutatási Alapprogramok (OTKA) kötelezővé tette a támogatás felhasználásával létrejövő eredmények open access közzétételét: „A vezetô kutató feladata, hogy az OTKA-támogatással létrejött tudományos közleményt a nyilt hozzáférés (Open Access) normái szerint téritésmentesen olvashatóvá tegye a szabad olvashatóság jogának. biztositásával, vagy a közlemény megjelenését követöen annak nyilvános hozzáférésú repozitóriumba való elhelyezésével." 6 A teljesítés támogatására hozta létre a Magyar Tudományos Akadémia Könyvtára a REAL repozitóriumot ${ }^{7}$ 2009-ben. Napjainkban már más kutatásfinanszírozó szervezetek is megkövetelik a támogatásból megvalósuló eredmények közzétételét, mint például a Nemzeti Kulturális Alap vagy a Bolyai János Kutatási Ösztöndíj. Az ilyen előírásokat gyüjti össze a Registry of Open Access Repositories Mandatory Archiving Policies (ROARMAP) ${ }^{8}$ adatbázis, mely az OTKA előírásán kívül még két hazait tart nyilván.

A Magyar Tudományos Akadémia elnöke 27/2012. (IX. 24.) határozatában intézkedett az akadémiai kutatóhálózatra vonatkozóan a tudományos múvek nyílt hozzáférésű közzétételének irányelveiről. ${ }^{9}$ A felsőoktatási intézmények szervezeti információmenedzsmentjének alapvető meghatározója a 2011. évi CCIV. törvény a nemzeti felsőoktatásról, mely 53/A. \(2) bekezdésében kötelezővé teszi a PhD dolgozatok és a tézisek közzétételét. ${ }^{10}$ Ennek teljesítése érdekében az intézményeknek repozitóriumot kell múködtetniük (vagy, ha ilyet nem tartanak fönn, egy sem intézményhez, sem tudományterülethez nem kötődő, ún. árva repozitórium szolgáltatását igénybe venni).

Nemzetközi szinten mind az Amerikai Egyesült Államok, mind az Európai Unió (hogy csak a legnagyobbakat említsük) kötelezővé teszi az állami támogatásból létrejött eredmények open access közzétételét. Az Európai Bizottság a $7^{\text {th }}$ Framework Program (FP7) keretében hozta létre az Open Access Pilot elnevezésú kísérleti kezdeményezést, mely azzal jár, hogy „, a folyóiratcikekeket kiadásuk.kor elektronikus adattárban is el kell helyezni, éspedig úgy, hogy az adattár a cik.khez nyilt hozzáférést biztositson vagy a megjelenést követöen azonnal (amennyiben maga a megjelentetés „nyilt hozzáférésüként” történik), vagy - szakterülettöl függöen - hat, illetve tizenkét hónappal a megjelenés után. A kisérleti kezdeményezésnek az a szélesebb értelemben vett célja, hogy javitsa a közfinanszírozásból végzett kutatás eredményeihez való hozzáférés feltételeit."'1 A Horizon 2020 finanszírozásban a publikációkhoz való nyílt hozzáférést már általános irányelvvé tette az Európai Bizottság, majd még egy lépéssel tovább ment: kísérletet indított a közfinanszírozásból létrejött kutatási adatok nyilt hozzáférésû közzétételére is. ${ }^{12}$ Az amerikai National Institutes of Health 2008 óta követeli meg, hogy a támogatásból megvalósult közlemények megjelenés előtti utolsó - azaz lektorált, de még nem tördelt - változata kerüljön be a PubMed Central-ba és 1 éven belül legyen nyilvánosan hozzáférhető. ${ }^{13}$ A szabályozás annyira alapvetővé vált, hogy a szakterület kiadói a legtöbb esetben maguk végzik el az archiválást. Ennek az open access politikának az országos kiterjesztését jelentette be John Holdren, a White House Office of Science and Technology Policy (OSTP) igazgatója 2013-ban. ${ }^{14}$ 
Bár az open access mozgalom még nagyon „fiatal”, és egyelőre számos szakterületen nem elterjedt, de a könyvtárak már felfigyeltek a változásokra és lépéseket is tesznek az új felhasználói igények kiszolgálására. Az open access publikációs modellben meg kell változnia a könyvtárak megszokott szerepének. Hagyományosan a könyvtárak nyomtatott dokumentumokat gyújtenek, dolgoznak fel és szolgáltatnak. Napjainkban, mikor a felhasználók az interneten, a Google-ban keresik az információt és digitális eszközökkel olvasnak, új gyüjtemények és szolgáltatások kialakítására van szükség.

A green open access közlési forma repozitóriumokat igényel - és hol lenne megfelelőbb helyen egy intézményben egy ilyen gyưjtemény, ha nem a könyvtárban, ahol már évszázadok óta dokumentumok gyűjtésével, feldolgozásával és szolgáltatásával foglalkoznak a szakemberek (kétségtelen, hogy a könyvtárosok képzésére is szükség van)?

Jelen pillanatban a green open access térhódítása jelentősebb, mint a gold open access vonalé (hiszen a kiadók maguk vállalják fel a repozitóriumi archiválást, sốt saját archívumokat hoznak létre), de tagadhatatlan, hogy egyre több open access folyóirat és egyre több open access kiadó jelenik meg a piacon (pl. PloS, BioMed Central, De Gruyter Open). A Directory of Open Access Journals (DOAJ) ${ }^{15}$ 2002-ben 26 open access folyóiratot listázott. Ez a szám rohamosan növekedett: 2003-ban már 611 db, 2004-ben 1220 db, 2005-ben 1848 db, 2006ban 2399 db, 2007-ben 2997 db, 2008-ban 3631 db, 2011-ben 7210 db, 2014. október 10én 10028 db, 2016. január 12-én pedig 11024 db open acces folyóiratot tartottak nyilván.

A könyvtárak ez utóbbi vonalon is számos szolgáltatást nyújthatnak az olvasók és a szerzők számára. Egyrészt az open access folyóiratok tartalmának szolgáltatása nagyon fontos feladatuk. Másrészt, ha számos folyóirat válik nyílt hozzáférésűvé, akkor az az előfizetési díjak egy részének megtakarítását eredményezi. De a publikálás költségét így is fedeznie kell valakinek - hiszen bár az online publikálás sokkal olcsóbb, mint a nyomtatott, mégsem kivitelezhető ingyen -, és ez az a „piaci rés”, amit kihasználhatnak a könyvtárak. A megtakarított összegek az open access publikálási díjakra fordíthatók, emellett a kiadóval való tárgyalás egy jelentôs hányadának terhét is le tudják venni a szerzők válláról.

Persze az új publikációs modellnek hátránya is akad. Sok olyan, ún. predátor folyóirat van jelen a piacon, melyek tudományos háttér nélkül működnek, kéretlen levelekben ajánlanak publikálási lehetőséget a kutatóknak, akik az őket terhelő közlési kényszer miatt élnek is a kínálkozó lehetôséggel. Azonban az így megjelent cikkek nem lektoráltak, és általában a tudományos folyóirat-kiadás más alapvető feltételeinek sem felelnek meg (pl. nincs, vagy komolytalan a szerkesztőbizottságuk). Az ilyen folyóiratok egyetlen célja a haszonszerzés. Nem könnyú megállapítani egy folyóiratról, hogy predátor-e vagy sem, de érdemes kerülni a gyanús orgánumokat, hiszen a kutatóra nem vet jó fényt, ha ilyen folyóiratban publikál. Ráadásul az így közölt cikk a szerző tudományos munkásságába már nem számítható be, hiszen az igazán komoly kiadók kerülik a másodközlést. Jeffrey Beall, a Colorado-i Egyetem könyvtárosa ad közre weboldalán egy listát, melyben felsorolja a nagy valószínűséggel predátor folyóiratokat. ${ }^{16}$

Jelen pillanatban még nem látjuk az open access publikálási modell minden előnyét és nehézségét. Vannak, akik a gold open access, vannak, akik a green open access meg- 


\section{BILICSI ERIKA}

valósításában látják a jövőt. De van olyan elképzelés is, mely még az open access közlési modellt is túllépi. Olyan publikációs megoldás lehetőségéről van szó, melyben a szerzők számára csak egyetlen publikációs platformot kell biztosítani. A tudósok ezen a felületen tehetnék közzé írásaikat, a tudományos közösség kommentek formájában végezné el a lektorálást. Az idézések száma igazolná az adott írás hasznosságát, a tudományos eredmény komolyságát, fontosságát. ${ }^{17}$

A természettudományi szakterület elindult a nyilt hozzáférésű közlés útján és - bár sokkal óvatosabban, de - követi a társadalom- és bölcsészettudomány is. Kiemelten fontos a fiatal kutatók, sőt már az egyetemisták tájékoztatása is az open access trenddel kapcsolatban. Ez a közlési forma jelentősen átalakítja a tudományos kommunikációt, melynek produktumai így még könnyebben érhetők el mind a tudományos kutatásban, mind az oktatásban résztvevők számára.

\section{Irodalom}

BÁNHEGYI Zsolt: Nyílt Hozzáférés Kezdeményezés (Open Access Initiative). Kitekintés és körkép. = Tudományos és Múszaki Tájékoztatás, 50. évf. 6-7. sz. 2003. 236-249. p. Forrás: http://tmt.omikk.bme.hu/show_news.html?id=2093\&issue_id=66 [2016. január 13.]

FORGÓ Sándor - TÓTH Tibor: Médiumismeret 2. Eszterházy Károly Főiskola. Forrás: http://www.tankonyvtar.hu/hu/tartalom/tamop425/0005_27_mediumismeret_ii_[-] scorm_02/32_az_informci_s_technika.html [2016.január 13.]

HOLL András: Információáradat és hullámlovaglás. = Magyar Tudomány, 174. évf. 4. sz. 2013. 473. p. Forrás: http://www.matud.iif.hu/2013/04/13.htm [2016. január 13.]

MAKARA B. Gábor: A tudományos közlés open access megoldásai 2000-2020 között. Előadás IS-IM 2013 konferencia, 2013.09.26. Forrás: https://lib.semmelweis.hu/app/getFile[-] \&id=1781 [2016. január 13.]

\section{Jegyzetek}

${ }^{1}$ Les grandes dates de l' Académie française. Forrás: http://www.academie-francaise.fr/[-] linstitution-lhistoire/les-grandes-dates [2016. január 13.]

${ }^{2}$ KORNIS Gyula: A tudomány társas szervezetei. In: Tudomány és társadalom: a tudomány szociológiája. Első kötet. Budapest, Franklin, 1944. 370-449. p.

3 Természetesen más kezdeményezések, ötletek is voltak, pl. az IFLA Publications sorozatban, 1981-ben megjelent Universal Availability of Publications (UAP), de elsőként a természettudomány képviselői cselekedtek. Ld. LINE, Maurice Bernard - VICKERS, Stephen C.: Universal Availability of Publications (UAP). München, New York, De Gruyter Saur, 1983. (IFLA Publications 25.) Forrás: http://www.degruyter.com/view/product/66137 [2016. január 13.]

${ }^{4}$ Budapest Open Access Initiative. Forrás: http://www.budapestopenaccessinitiative.org [2016. január 13.]

${ }^{5}$ Berlin Declaration. Forrás: http://oa.mpg.de/openaccess-berlin/berlindeclaration.html [2016. január 13.] 
${ }^{6}$ OTKA. Az OTKA Támogatási Szerződések Teljesítésének Szabályainak 7.10-es pontja alapján. Forrás: http://www.otka.hu/open-access [2016. január 13.]

${ }^{7}$ REAL. Forrás: http://real.mtak.hu [2016. január 13.]

8 A ROARMAP (Registry of Open Access Repositories Mandatory Archiving Policies) mintegy 350 open access mandátumot tart nyilván. ROARMAP. Forrás: http://roarmap.eprints.org [2016. január 13.]

9 A Magyar Tudományos Akadémia elnökének 27/2012. (IX. 24.) határozata. Forrás: http://[-] mta.hu/data/cikk/11/97/91/cikk_119791/27_2012_elnoki_hat_Open_Access.pdf [2016. január 13.]

10 2011. évi CCIV. törvény a nemzeti felsőoktatásról. Forrás: http://net.jogtar.hu/jr/gen/[-] hjegy_doc.cgi?docid=A1100204.TV [2016. január 13.]

${ }^{11}$ Model cover letter for amendment to publishing agreement. Forrás: http://ec.europa.eu/[-] research/science-society/index.cfm?fuseaction=public.topic\&id=1300\&lang=1 [2016. január 13.]

${ }^{12}$ Tudományos adatok: a kutatási eredményekhez való nyílt hozzáférés lökést ad az európai innovációnak (Sajtóközlemény). Forrás: http://europa.eu/rapid/press-release_IP-12-790_[-] hu.htm [2016. január 13.] A bizottság ajánlása (2012. július 17.) a tudományos információkhoz való hozzáférésről és azok megőrzéséről (2012/417/EU). Forrás: http://eur-lex.europa.[-] eu/LexUriServ/LexUriServ.do?uri=OJ:L:2012:194:0039:0043:HU:PDF [2016. január 13.]

${ }^{13}$ What is the NIH Public Access Policy? Forrás: http://publicaccess.nih.gov/faq.htm\#753 [2016. január 13.]

${ }^{14}$ White House announces new OS open acces policy. Forrás: http://blogs.nature.com/[-] news/2013/02/us-white-house-announces-open-access-policy.html [2016. január 13.]

${ }^{15}$ DOAJ. Forrás: http://doaj.org/about; Görögh Edit: Az EU 7. keretprogram tudományos eredményeinek disszeminációja. Forrás: http://www.open-access.hu/sites/www.open-[-] access.hu/files/OpenAIRE_OA\%20week.ppt [2016. január 13.]

${ }^{16}$ List of predatory journals. Forrás: http://scholarlyoa.com/publishers [2016. január 13.]

${ }^{17}$ Elhangzott Bernard Rentier, a Liege-i Egyetem rektorának az open access megvalósításának gyakorlatát bemutató előadásában a 2015. október 29-30-án, Budapesten rendezett Working Together to Promote Open Access Policy Alignment in Europe címú konferencián.

Bilicsi Erika a tanulmány írásakor a Magyar Tudományos Akadémia Könyvtár és Információs Központ Szakinformatikai Osztályának könyvtárosa, majd 2016-tól osztályvezetője. 2012 óta a REAL repozitórium munkatársa, 2014 óta DOI regisztrációval kapcsolatos feladatokat is ellát. Résztvevője a könyvtár PASTEUR4OA projektjének, melynek célja az európai open access politikák összehangolása. 2015 óta segíti az EURODOC open access munkacsoportjának munkáját. Az ELTE Irodalomtudományi Doktori Iskola Könyvtártudomány Doktori Programjának hallgatója. 